\title{
Female Reproductive Strategies of Marine Fish Species of the North Atlantic
}

\author{
H. Murua \\ AZTI Foundation, Herrera Kaia - Portualde z/g \\ 20110 Pasaia, Basque Country, Spain \\ and \\ F. Saborido-Rey \\ Institute of Marine Research, Eduardo Cabello, 6 \\ 36208 Vigo, Spain
}

\begin{abstract}
This contribution describes and identifies the most common reproductive strategies of a large number of commercially important fish species of the North Atlantic with regard to oocyte development, ovary organization, recruitment of oocytes and spawning pattern. Groupsynchronous ovary organization, determinate fecundity and batch spawning was the most common suite of associated reproductive traits observed among North Atlantic fishes (e.g., gadoids, pleuronectoids). Another common type of female reproductive strategy among these species was synchronous, determinate and total spawning which occurred in a number of semelparous (eels, Anguilla sp., capelin, Mallotus villosus) and iteroparous species (e.g., redfishes, Sebastes sp., monkfishes, Lophius sp., herring, Clupea harengus, and elasmobranchs). Asynchronous, indeterminate and batch spawning occurred among anchovies, Engraulis sp., European hake, Merluccius merluccius, mackerels, Scomber sp. and Trachurus sp., swordfish, Xiphias gladius, and others. Categorization of species according to reproductive strategy assists in the estimation of species-specific fecundity and reproductive potential using various developed protocols.
\end{abstract}

Key words: fecundity, life history, marine fish, North Atlantic, ovary, oocyte development, reproductive strategy, spawning pattern

\section{Introduction}

Natural selection leads to the maximization of lifetime production of offspring, and more importantly to the maximization of survivorship of offspring until adulthood. The main objective of a reproductive strategy is to maximize reproductively active offspring in relation to available energy and parental life expectancy (Wootton, 1984; Roff, 1992; Pianka, 2000). In order to achieve this, fish follow different strategies and tactics (Balon, 1984; Ware, 1984). The reproductive strategy of a species is the overall pattern of reproduction common to individuals of a species, whereas the reproductive tactics are those variations in response to fluctuations in the environment (Wootton, 1984, 1990; Roff, 1996). It is assumed that both the overall strategy and the tactical variations are adaptive (Stearns, 1992). Fishes exhibit great diversity in reproductive strategies and associated traits
(Helfman et al., 1997) such as breeding system, number of partners, gender role, spawning habitat, spawning season, fecundity and others (Table 1).

Most marine fish species of commercial importance are iteroparous, that is they spawn more than once during their lives, and gonochoristic, that is their sexes are separate, possess no sexual dimorphism, and exhibit external fertilization without parental care. There are, of course, significant exceptions to this general rule, for example, Pacific salmonids (Oncorhynchus sp.), capelin (Mallotus villosus) and eels (Anguilla sp.) are semelparous, that is they spawn once in their lives and die. Fishes of the genus Sebastes (Atlantic redfishes and Pacific rockfishes) and some elasmobranchs are viviparous species, that is their embryos develop inside the ovary, with internal fertilization of eggs. Viviparity in Sebastes species is lecithotrophic, which means that larvae absorb nutrients from yolk accumulated 
TABLE 1. Summary of different reproductive strategies based on different components of breeding systems in marine fishes (Source: Wootton, 1990).

I. Number of breeding opportunities

A. Semelparous (spawn once and die): lampreys, river eels, capelin, Pacific salmons.

B. Iteroparous (multiple breeding seasons): most species.

II. Type of spawning

A. Total spawners. Eggs are released in a single episode in each breeding season.

B. Batch spawners. Eggs are released in batches over a period that can last days or even months.

III. Mating system

A. Promiscuous (both sexes with multiple partners during breeding season): herring, cod, etc.

B. Polygamous, including monogamy (sculpins, sunfishes, etc.)

IV. Gender system

A. Gonochoristic (sex fixed at maturation): most species.

B. Hermaphroditic (sex may change after maturation). Sea basses.

V. Secondary sexual characteristics (traits not associated with fertilization or parental care)

A. Monomorphic (no distinguishable external difference between sexes): most species.

B. Sexually dimorphic (permanent, seasonal or polymorphic). Pacific salmon.

VI. Spawning site preparation

A. No preparation: most species of broadcast spawners.

B. Site prepared and defended. Salmons.

VII. Place of fertilization

A. External: most species.

B. Internal: elasmobranches, Sebastes sp., etc.

VIII.Embryonic development

A. Oviparity. Embryos develop outside the ovary, so eggs are released at spawning.

B. Viviparity. Embryos develop inside the ovary, so embryos or larvae are released at spawning.

IX. Parental care

A. No parental care: most species.

B. Parental care (male, female or bi-parental care). Seahorses, rockfishes.

previously in the egg (formerly known as ovoviviparity). However, energetic studies have shown that, in at least two Pacific Sebastes species (S. melanops and $S$. schlegeli), females provide food to developing embryos, that is their viviparity is matrotrophic, at least partially (Boehlert and Yoklavich, 1984 Boehlert et al., 1986). Most commercial species release a large number of pelagic eggs. However, some important species produce benthic eggs that adhere to substrates or are buried (e.g. herring, Clupea harengus, Atlantic salmon, Salmo salar, and capelin). Monkfishes (Lophius sp.) deposit eggs as a mucous sheet or veil that floats at the water's surface. Finally, Sebastes species and some elasmobranchs release live larvae or juveniles.

In fisheries biology, analysis of life history traits related to reproduction has mainly focused on females, in part because offspring production is limited to a 
greater degree by egg production than sperm production (Helfman et al., 1997). Additionally, the female contributes nourishment to the developing embryo and thus at least during the very early life stages the maternal role is more important than the paternal role in influencing progeny production. Nevertheless, this perspective is being broadened and increasing attention has been given to male reproductive characteristics in relation to offspring production (Trippel and Neilson, 1992; Evans and Geffen, 1998; Rakitin et al., 1999; Trippel, 2003).

Reproductive potential is a measure of the capacity of a population to produce viable eggs and larvae, and can be considered as the main outcome of a reproductive strategy. Several factors have been identified which influence stock reproductive potential, such as spawning stock biomass (Bagenal, 1973; Myers and Barrowman, 1996), adult age structure and diversity (Alheit et al., 1983; Cardinale and Arrhenius, 2000), the proportion of first-time and repeat spawners (Evans et al., 1996; Trippel, 1998), nutritional condition (Hislop et al., 1978; Hunter and Leong, 1981; Brooks et al., 1997) and, age and size at sexual maturity (Roff, 1981; Morgan and Hoening, 1997).

The objective of this contribution is to describe and identify the most common female reproductive strategies of commercially important species of the North Atlantic with regard to oocyte development and ovarian organization, spawning pattern and fecundity. The identification of the mode by which mature eggs are developed and spawned is required to appropriately estimate the fecundity and reproductive potential of a species (Murua et al., 2003).

\section{Oocyte Development and Ovarian Organization}

Oocytes develop within the ovary through different stages. Although some differences occur among species, the sequence of oocyte developmental stages can be generalized among teleost fish species in four main stages: primary growth, cortical alveoli or yolk vesicle formation, vitellogenesis and maturation (Fig. 1) (Wallace and Selman, 1981; West, 1990; Tyler and Sumpter, 1996).

Oocytes in the primary growth stage do not contain yolk and constitute a "reserve fund", for future breeding seasons. The appearance of yolk proteins (cortical alveoli vesicles) in granules or organelles in the cytoplasm is characteristic of the cortical alveoli stage and indicates that the oocytes will normally continue their development through the remaining stages within the current breeding season. Concomitant with oocyte growth, the cortical alveoli vesicles increase in size and number to form several peripheral rows. The cortical alveoli vesicles will release their contents into the perivitelline space, inside the egg membranes, during fertilization (Wallace and Selman, 1981). In species in which the eggs contain an oil globule, oil droplets begin to accumulate in the cytoplasm in this stage.

The next stage, vitellogenesis, is characterized by the appearance of "true" yolk vesicles in the cytoplasm of oocytes. The oocytes increase considerably in size as the yolk accumulates. Vitellogenesis ceases once oocytes reach their fully developed size and these eventually undergo maturation and ovulation after appropriate hormonal stimulation (Masui and Clarke, 1979).

The start of the maturation stage is indicated by the migration of the nucleus to the animal pole. When the nucleus has completed its migration, the first meiotic division takes place. The hydration phase begins in many species at the end of the maturation stage, just prior to ovulation; this stage consists of a rapid uptake of fluid by the oocyte through its follicle and the coalescence of yolk spheres and/or oil droplets (Fulton, 1898). This process is especially pronounced in species that spawn pelagic eggs. After ovulation the second meiotic division occurs and the oocyte becomes an egg.

Based upon the dynamics of the organization of the ovary, Marza (1938) and Wallace and Selman (1981) defined three types of ovarian development organization:

Synchronous. All the oocytes develop and ovulate at the same time; thus, further replenishment from earlier stages does not take place. Such ovaries may be found in teleosts that spawn once and then die, such as anadromous Oncorhynchus species, in catadromous eels or in capelin. The oocyte diameter frequency distribution is represented by a single bell curve (Fig. 2a).

Group-synchronous. At least two populations of oocytes can be recognized at any one time; a fairly synchronous population of larger oocytes (defined as a "clutch") and a more heterogeneous population of smaller oocytes from which the clutch is recruited (Fig. $2 b$ ). The former are the oocytes to be spawned during the current breeding season, while the latter are the oocytes to be spawned in future breeding seasons. 


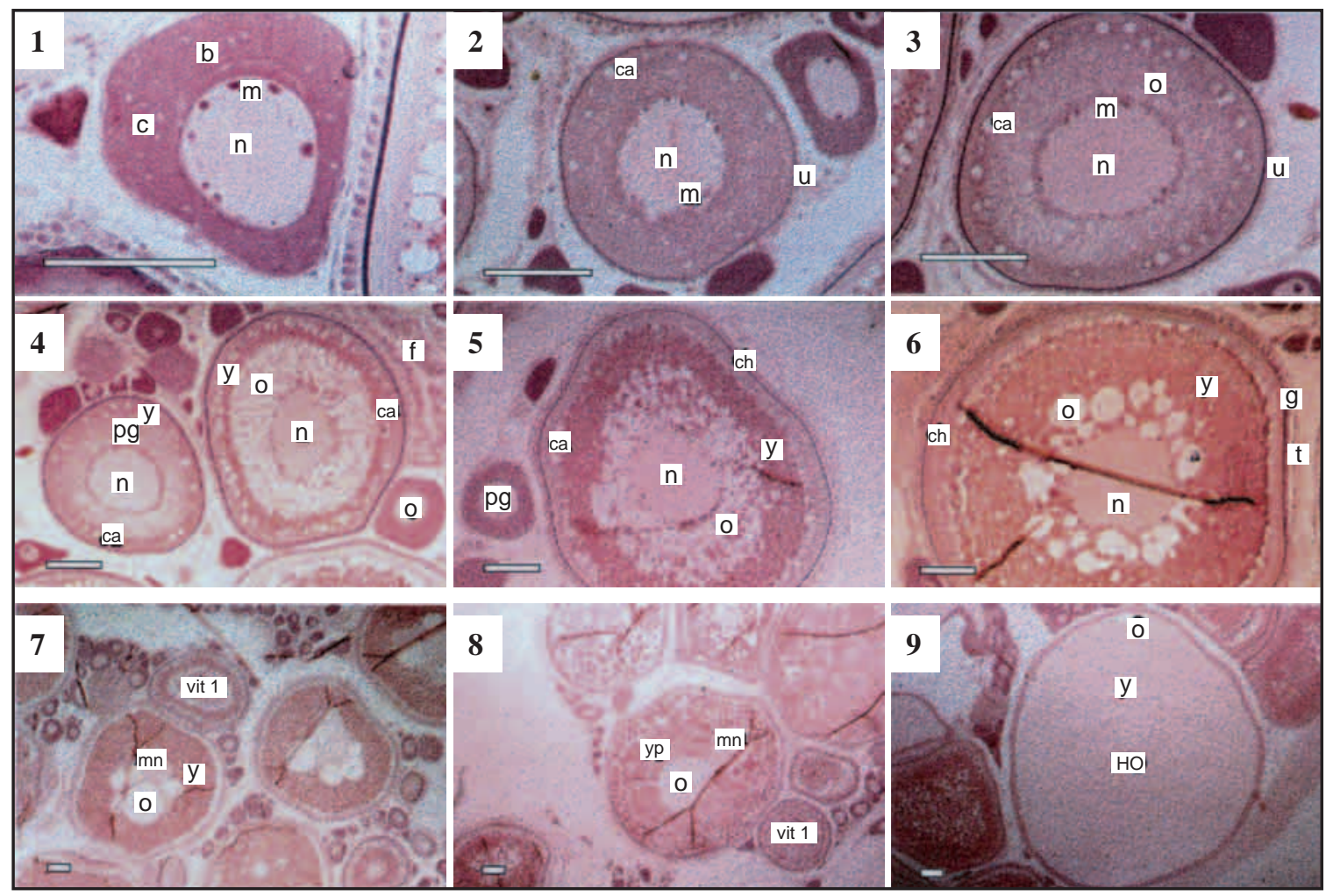

Fig. 1. Oocyte development process (1 to 9) in European hake, Merluccius merluccius, from Murua and Motos (MS 1996); example of asynchronous ovary organization. (1) "primary growth" stage oocyte; (2), (3) "cortical alveoli" stage oocyte; (4) cortical alveoli oocyte (left) and early vitellogenic oocyte (right); (5), (6) advanced vitellogenic oocytes; (7) early migration (maturation) stage; (8) migration stage (final maturation); and (9) hydrated oocyte.

n: nucleus; m: nucleolus; c: cytoplasm; ca: cortical alveoli; pg: primary growth; t: follicle layer; u: envelope of oocyte; y: yolk vesicles; o: oil droplets; mn: migratory nucleus; yp: yolk plates; HO: hydrated oocyte; b: balbiani bodies; ch: chorion; g: granulosa; t: theca; and vit 1: vitellogenic oocyte; f: postovulary follicle. Bar $=0.1 \mathrm{~mm}$.

Such ovaries may be found in iteroparous species, with a relatively short spawning season and where the yolk accumulation mostly depends on body reserves, such as Atlantic cod (Gadus morhua), haddock (Melanogrammus aeglefinus), pollock (Pollachius virens), American plaice (Hippoglossoides platessoides), Greenland halibut (Reinhardtius hippoglossoides), roughhead grenadier (Macrourus berglax), roundnose grenadier (Coryphaenoides rupestris), flounders, redfishes, and in most of the other demersal species inhabiting cold marine waters.

Asynchronous. Oocytes of all stages of development are present without dominant populations. The ovary appears to be a random mixture of oocytes, at every conceivable stage. Only when hydration occurs is there a clearly separate stock of oocytes with regard to diameter (a clear separation appears between advanced yolked oocytes and hydrated oocytes), as shown in Fig. 2c. Such ovaries may be found in iteroparous species, with protracted spawning seasons and where yolk accumulation, and hence oocyte development, relies mostly on the food available in the environment at that moment (Hunter and Leong, 1981), and occurs in European hake (Merluccius merluccius), Atlantic mackerel (Scomber scombrus), anchovies (Engraulis sp.) and in general in small pelagic species in temperate waters.

\section{Spawning Pattern}

Based upon the rhythm that oocytes are ovulated, i.e., they are spawned, Tyler and Sumpter (1996) described two types of spawning patterns. The term "synchronous ovulators" refers to species where the whole clutch of yolked oocytes ovulates at once and the eggs are shed in a unique event or over a short period of time, a week or two according to Holden and Raitt (1974), but as part of a single episode. These 

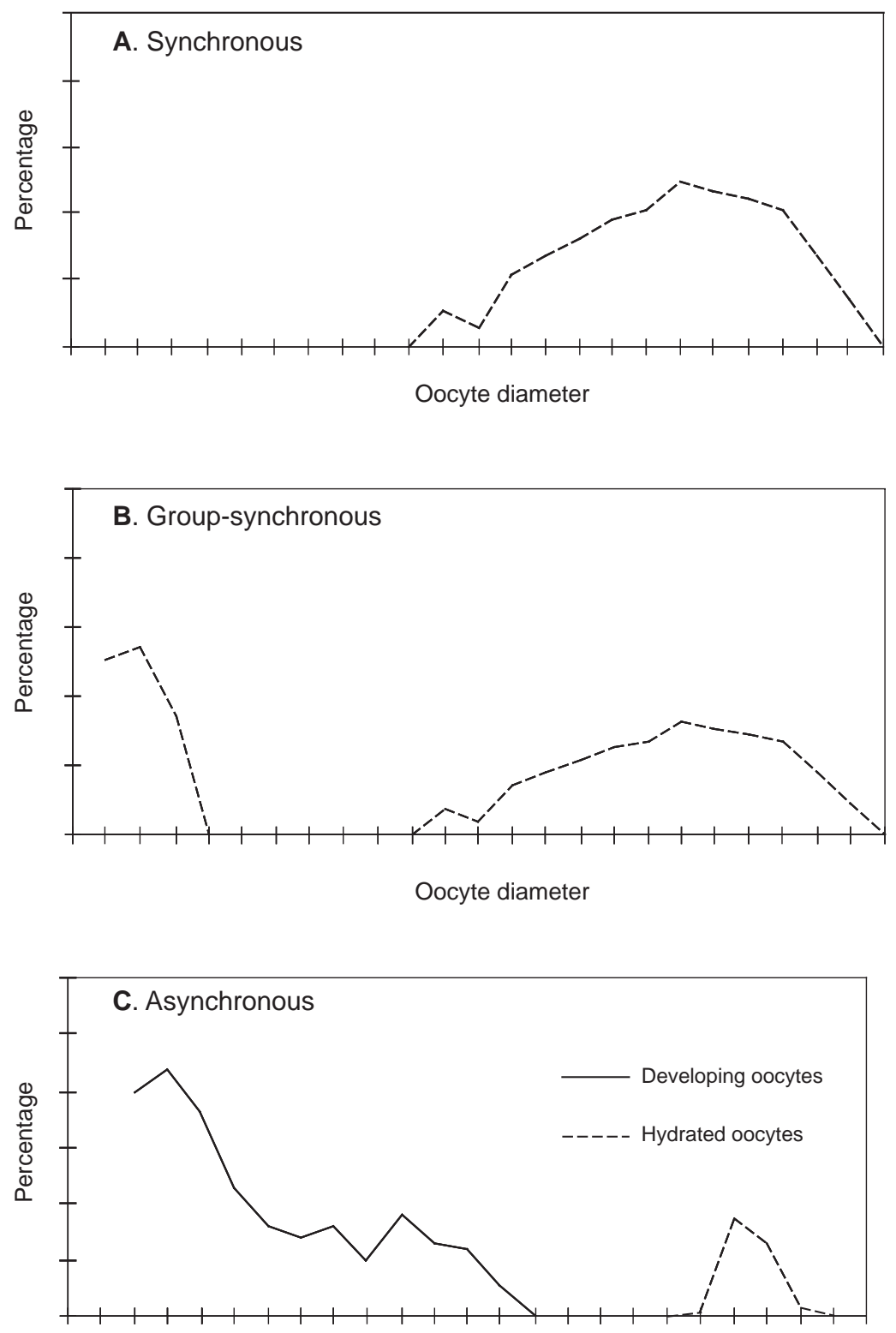

Oocyte diameter

Fig. 2. Oocyte-size frequency for the three different types of ovarian organization: (A) synchronous, (B) group-synchronous and (C) asynchronous. Axes values not provided as represents a hypothetical example.

species are known also as total spawners and includes species such as monkfishes, redfishes, salmonids, elasmobranchs and eels. In contrast, in "asynchronous ovulators", eggs are recruited and ovulated from the population of yolked oocytes in several batches over a protracted period during each spawning season. These species are also called batch spawners. Only a portion of the yolked oocytes is spawned in each batch, usually through the hydration process. Most of the cold and temperate water commercially important species of the Atlantic are batch spawners, although the number of batches and the duration of their spawning season varies considerably.

Batch spawning can be seen as a strategy to release eggs over a long period of time increasing the survival probability of offspring (Lambert and Ware, 1984). Also it can be seen as a necessity in highly 
fecund species where a physical limitation occurs when the hydration phase of oocytes takes place markedly increasing the volume of eggs and expanding the body cavity (Bagenal, 1978; Fordham and Trippel, 1999).

\section{Fecundity}

Although fecundity is described as the number of eggs produced by a female, there exist a variety of terms describing the different facets of fecundity: Potential annual fecundity is defined as the total number of advanced yolked oocytes matured per year, uncorrected for atretic losses (Hunter et al., 1992). Annual realized fecundity, however, is the actual (or real) number of eggs finally released, so it is equal to or lower than the potential fecundity, since some of the eggs can be reabsorbed through atresia during spawning, or simply that some of the eggs are not able to be liberated, remaining in the ovary and being reabsorbed later. Total fecundity is defined as the standing stock of advanced yolked oocytes at any time (Hunter et al., 1992). Batch fecundity is the number of eggs spawned in each batch, and consequently, the sum of batch fecundities is the realized annual fecundity. Finally, annual population fecundity is the number of eggs that all the females in a population spawn in a breeding season (Bagenal, 1978).

Two types of fecundity have been described with regard to the strategy by which oocytes are recruited to the advanced stock of yolked oocytes to be shed (Hunter et al., 1992):

Determinate Fecundity. In fishes with determinate fecundity, total fecundity prior to the onset of spawning is considered to be equivalent to the potential annual fecundity. After correcting for atretic losses, the total number of eggs released per female in a year is termed the realized annual fecundity. In batchspawning species, the number of yolked oocytes remaining in the ovary decreases with each spawning event (batch) because the standing stock of yolked oocytes is not replaced during the spawning season (Hunter et al., 1992). This type of fecundity may be found in Atlantic cod, haddock, pollock, Atlantic mackerel, whiting (Merlangus merlangus), roughhead grenadier, roundnose grenadier, Greenland halibut, sole (Solea solea), redfishes, monkfishes and elasmobranchs.

Indeterminate Fecundity. This term refers to species where potential annual fecundity is not fixed before the onset of spawning and unyolked oocytes continue to be matured and spawned during the spawning season (Hunter et al., 1992). In such species, the standing stock of previtellogenic oocytes can develop and be recruited into the yolked oocyte stock at any time during the season (de novo vitellogenesis) (Hunter and Goldberg, 1980). Estimation of the standing stock of advanced oocytes in the ovary is meaningless if, during the spawning season, oocytes are recruited to that stock. Alternatively, the annual fecundity of this species should be calculated by estimation of the number of oocytes spawned per batch, the percentage of females spawning per day (spawning fraction), and the duration of the spawning season (Hunter et al., 1985). This type of fecundity may be found in anchovies, European hake, chub mackerel (Scomber japonicus), horse mackerel (Trachurus trachurus) and pilchard (Sardina pilchardus).

In light of these issues, Hunter et al. (1992) and Greer Walker et al. (1994) provide four lines of evidence to identify whether the fecundity of a given species is determinate or indeterminate, namely:

i) The variation in the stage-specific oocyte size frequency distribution during the annual reproductive cycle. A distinct hiatus separating the yolked oocyte stock from the reservoir of unyolked oocytes, typical of synchronous and group-synchronous species, indicates that annual fecundity is determinate, whereas the lack of a hiatus may indicate that annual fecundity is indeterminate. However, the lack of a hiatus does not necessarily indicate that fecundity is indeterminate (Hislop and Hall, 1974; using captive fish experiments).

ii) The evolution of the number of advanced yolked oocytes in the ovary (total fecundity). A decrease in the ovary's stock vitellogenic oocytes during the spawning season provides evidence for determinate fecundity. Total fecundity, in determinate species, decreases with each batch because the standing stock of yolked oocytes is not replaced during the spawning season, that is the standing stock of advanced vitellogenic oocytes is lower in females having post-ovulatory follicles (females that have already started to spawn).

iii) In fishes with determinate fecundity a seasonal increase in the mean diameter of the advanced vitellogenic oocytes may be expected over the spawning season, because no new yolked oocytes are recruited to replace those that have been spawned during the 
season. However, the diameter of the advanced yolked oocytes (which are in vitellogenesis) remains constant or declines as the spawning season progresses in some species with determinate fecundity, for example in mackerel (Greer Walker et al., 1994).

iv) The incidence of atresia during the spawning season also differs between species exhibiting determinate and indeterminate fecundity. Fishes with indeterminate fecundity show a generalized prevalence of atresia and resorption of mature oocytes at the end of the spawning season (West, 1990; Greer Walker et al., 1994), while fishes with determinate fecundity, atresia rarely is generalized and, if present, it is distributed sparsely along the reproductive season (Hunter et al., 1992).

\section{Summary}

Marine fishes exhibit wide heterogeneity in reproductive strategies, and a key issue in the estimation of the egg production of any species is to correctly identify its reproductive strategy. Consequently, we have categorized various commercially important marine fish species according to their reproductive strategy, that is regarding their oocyte development, fecundity type and spawning pattern (Table 2). Oocyte development may be either synchronous, group-synchronous, or asynchronous. Fecundity may be either determinate or indeterminate.

TABLE 2. Female reproductive strategies of marine fish species according to oocyte and egg development, recruitment of oocytes, and spawning pattern.

\begin{tabular}{|c|c|c|c|c|}
\hline $\begin{array}{l}\text { Breeding } \\
\text { opportunities }\end{array}$ & $\begin{array}{c}\text { Ovarian } \\
\text { organization }\end{array}$ & $\begin{array}{l}\text { ductive Strategy } \\
\text { Fecundity } \\
\text { type }\end{array}$ & $\begin{array}{l}\text { Spawning } \\
\text { pattern }\end{array}$ & Examples \\
\hline Semelparous & Synchronous & Determinate & Total spawner & $\begin{array}{l}\text { Pacific salmons (Oncorhynchus sp.) } \\
\text { Eels (Anguilla } \mathrm{sp} .) \\
\text { Capelin (Mallotus villosus) }\end{array}$ \\
\hline \multirow[t]{4}{*}{ Iteroparous } & Group-Synchronous & Determinate & Total spawner & $\begin{array}{l}\text { Redfishes (Sebastes sp.) } \\
\text { Monkfishes (Lophius sp.) } \\
\text { Herring (Cuplea harengus) } \\
\text { Atlantic Salmon (Salmo salar) } \\
\text { Sea trout (Salmo rutta) } \\
\text { Elasmobranchs }\end{array}$ \\
\hline & & & Batch spawner & $\begin{array}{l}\text { Cod (Gadus morhua) } \\
\text { Haddock (Melanogrammus eglefinus) } \\
\text { Saithe/Pollock (Pollachius virens) } \\
\text { Roughhead grenadier (Macrourus berglax) } \\
\text { Roundnose grenadier (Coryphaenoides rupestris) } \\
\text { Yellowtail flounder (Limanda ferruginea) } \\
\text { Greenland halibut (Reinhardtius hippoglossoides) } \\
\text { Atlantic halibut (Hippoglossus hippoglossus) } \\
\text { American plaice (Hippoglossoides platessoides) } \\
\text { Dab (Limanda limanda) } \\
\text { Plaice (Pleuronectes platessa) } \\
\text { Bass (Dicentrarchus labrax) } \\
\text { Winter flounder (Pseudopleuronectes } \\
\text { americanus) } \\
\text { Turbot (Scophthalmus maximus) } \\
\text { Whiting (Merlangus merlangus) }\end{array}$ \\
\hline & Asynchronous & Determinate & Batch spawner & $\begin{array}{l}\text { Atlantic mackerel (Scomber scombrus) } \\
\text { Sole (Solea solea) }\end{array}$ \\
\hline & & Indeterminate & Batch spawner & $\begin{array}{l}\text { Anchovies (Engraulis sp.) } \\
\text { European hake (Merluccius merluccius) } \\
\text { Chub mackerel (Scomber japonicus) } \\
\text { Horse mackerel (Trachurus trachurus) } \\
\text { Yellowfin tuna (Thunnus albacares) } \\
\text { Pilchard (Sardina pilchardus) } \\
\text { Atlantic swordfish (Xiphias gladius) }\end{array}$ \\
\hline
\end{tabular}


Mature eggs within a spawning season may be released either collectively (total spawner) or as discrete batches (batch spawner). Group-synchronous ovary organization, determinate fecundity and batch spawning was the most common suite of associated reproductive traits observed among North Atlantic fishes (e.g., gadoids, pleuronectoids). Another common type of female reproductive strategy among North Atlantic fishes was synchronous oocyte development, determinate fecundity, and total spawning which occurred in a number of semelparous (e.g., eels, capelin) and iteroparous species (e.g., redfishes, monkfishes, herring and elasmobranchs). Asynchronous oocyte development, indeterminate fecundity, and batch spawning occurred among anchovies, European hake, mackerels, swordfish and others.

This wide spectrum of female reproductive strategies supports a diversity of adaptive processes by which species have adapted and populated the marine environment. In addition to aiding in assessing fecundity, understanding these mechanisms of reproduction could also lead to greater comprehension of the underlying mechanisms of variable fish recruitment.

\section{Acknowledgements}

The authors are indebted to all those who at different stages helped in the preparation of our manuscript. We especially thank our colleagues and friends of the NAFO Working Group on Reproductive Potential; and greatly appreciate the helpful comments and suggestions provided by Ed Trippel and two anonymous referees that led to the improvement of this manuscript.

\section{References}

AlHEIT, J., B. ALEGRE, V. H. ALARCÓN, and B. J. MACEWICZ. 1983. Batch fecundity and spawning frequency of various anchovy (Genus: Engraulis) populations from upwelling areas and their use for spawning biomass estimates. FAO Fish. Rep., 291: $977-985$.

BAGENAL, T. B. 1973. Fish fecundity and its relations with stock and recruitment. ICES Rapp. Proc.-Verb., 164: 186-198.

1978. Aspects of fish fecundity. In: Ecology of freshwater fish production. S. D. Gerking (ed.). Third edition, Blackwell, Oxford, p. 75-101.

BALON, E. K. 1984. Patterns in the evolution of reproductive styles in fishes. In: Fish reproduction: strategies and tactics. G. W. Potts and R. J. Wootton (eds.). Academic Press, New York, p. 35-53.

BOEHLERT G. W., and M. M YOKLAVICH. 1984. Reproduction, embryonic energetics, and the maternalfetal relationship in the viviparous genus Sebastes (Pisces: Scorpaenidae). Biol. Bull., 167: 354-370.

BOEHLERT G. W., M. KUSAKARI and J. YAMADA. 1987. Reproductive mode and energy costs of reproduction in the genus Sebastes. In: Proceedings of the International Rockfish Symposium. Lowell Wakefield Fisheries Symposium, Anchorage, Alaska USA. G. W. Boehlert, M. Kusakari, J. Yamada, and B. R. Melteff (eds.). Alaska Sea Grant Report 87 (02), University of Alaska, Fairbanks, Alaska, p. 143-152.

BROOKS, S., C. R. TYLER, and J. P. SUMPTER. 1997. Egg quality in fish: what makes a good egg? Rev. Fish Biol. Fish., 7: 387-416.

CARDINALE M. and F. ARRHENIUS. 2000. The influence of stock structure and environmental conditions on the recruitment process of Baltic cod estimated using a generalized additive model. Can. J. Fish. Aquat. Sci., 57: 2402-2409.

EVANS, J. P., and A. J. GEFFEN. 1998. Male characteristics, sperm traits, and reproductive success in winterspawning Celtic Sea Atlantic herring, Clupea harengus. Mar. Biol., 132: 179-186.

EVANS, R. P., C. C. PARRISH, J. A. BROWN, and P. J. DAVIS. 1996. Biochemical composition of eggs from repeat and first-time spawning captive Atlantic halibut (Hippoglossus hippoglossus). Aquaculture, 139: 139-149.

FORDHAM, S. E., and E. A. TRIPPEL. 1999. Feeding behaviour of cod (Gadus morhua) in relation to spawning. J. Appl. Ichthyol., 15: 1-9.

FULTON, T. W. 1898. On the growth and maturation of the ovarian eggs of the teleostean fishes. Ann. Rep. Fish. Board Scotl., 16: 88-124.

GREER WALKER, M., P. R. WITTHAMES, and J. I. BAUTISTA DE LOS SANTOS. 1994. Is the fecundity of the Atlantic mackerel (Scomber scombrus) determinate? Sarsia, 79: 13-26.

HELFMAN, G. S., B. B. COLLETTE, and D. E. FACEY. 1997. The diversity of fishes. Blackwell Science, London, England, 529 p.

HISLOP, J. R. G., and W. B. HALL. 1974. The fecundity of whiting, Merlangus merlangus (L.), in the North Sea, the Munch and at Iceland. ICES J. Cons., 36: 162-165.

HISLOP, J. R. G, A. P. ROBB and J. A. GAULD. 1978. Observations on effects of feeding level on growth and reproduction in haddock, Melanogrammus aeglefinus (L.), in captivity. J. Fish. Biol., 13: 85-98.

HOLDEN, M. J., and D. F. S. RAITT. 1974. Manual of fisheries science. 2. Methods of resource investigation and their application. FAO Fish. Tech. Pap., No. 115, Rev. 1, 211 p.

HUNTER, J. R., and S. R. GOLDBERG. 1980. Spawning incidence and batch fecundity in northern anchovy, Engraulis mordax. Fish. Bull. U.S., 77: 641-652.

HUNTER, J. R., and R. J. H. LEONG. 1981. The spawning energetics of female northern anchovy, Engraulis mordax. Fish. Bull. U. S., 79: 215-230. 
HUNTER, J. R., N. C. H. LO, and R. J. H. LEONG. 1985. Batch fecundity in multiple spawning fishes. In: An egg production method for estimating spawning biomass of pelagic fish: Application to the northern anchovy, Engraulis mordax. R. Lasker (ed.). NOAA Tech. Rep. NMFS, 36: 67-78.

HUNTER, J. R., B. J. MACIEWICZ, N. C. H. LO, and C. A. KIMBRELL. 1992. Fecundity, spawning, and maturity of female Dover Sole, Microstomus pacificus, with an evaluation of assumptions and precision. Fish. Bull. U.S., 90: 101-128.

LAMBERT, T. C., and D. M. WARE. 1984. Reproductive strategies of demersal and pelagic spawning fish. Can. J. Fish. Aquat. Sci., 41: 1565-1569.

MARZA, V. D. 1938. Histophysiologie de l'ovogenese. Hermann, Paris, $81 \mathrm{p}$.

MASUI, Y., and H. J. CLARKE. 1979. Oocyte maturation. Internat. Rev. Cyt., 57: 185-282.

MORGAN, M. J., and J. M. HOENIG. 1997. Estimating maturity-at-age from length stratified sampling. J. Northw. Atl. Fish. Sci., 21: 51-64.

MURUA, H., and L. MOTOS. MS 1996. Reproductive modality and batch fecundity of the European hake, Merluccius merluccius. ICES C.M. Doc., No. G:40., $23 \mathrm{p}$.

MURUA, H., G. KRAUS, F. SABORIDO-REY, P. R. WITTHAMES, A. THORSEN, and J. JUNQUERA. 2003. Procedures to estimate fecundity of marine fish species in relation to their reproductive strategy. J. Northw. Atl. Fish. Sci., 33: 33-53.

MYERS, R.A., and N. J. BARROWMAN. 1996. Is fish recruitment related to spawner abundance? Fish. Bull. U.S., 94: 707-724.

PIANKA, E. R. 2000. Evolutionary ecology. Sixth edition. Benjamin-Cummings, Addison-Wesley-Longman. San Francisco, 528 p.

RAKITIN, A., M. M. FERGUSON, and E. A. TRIPPEL. 1999. Sperm competition and fertilization success in Atlantic cod (Gadus morhua): effect of sire size and condition factor on gamete quality. Can. J. Fish. Aquat.
Sci., 56: 2315-2323.

ROFF. D. A. 1981. Reproductive uncertainty and the evolution of iteroparity: why don't flatfish put all their eggs in one basket? Can. J. Fish. Aquat. Sci., 38: 968-977.

ROFF, D. A. 1992. The evolution of life histories: theory and analysis. Chapman and Hall, New York, 528 p.

1996. The evolution of threshold traits in animals. Quart. Rev. Biol., 71: 3-35.

STEARNS, S. C. 1992. The evolution of life histories. Oxford University Press, Oxford, 262 p.

TRIPPEL, E. A. 1998. Egg size and viability and seasonal offspring production of young Atlantic cod. Trans. Am. Fish. Soc., 127: 339-359.

TRIPPEL, E. A. 2003. Estimation of male reproductive success of marine fishes. J. Northw. Atl. Fish. Sci., 33: 81-113 (this volume).

TRIPPEL, E.A. and J. D. NEILSON. 1992. Fertility and sperm quality of virgin and repeat-spawning Atlantic cod (Gadus morhua) and associated hatching success. Can. J. Fish. Aquat. Sci., 49: 2118-2127.

TYLER, C. R., and J. P. SUMPTER. 1996. Oocyte growth and development in teleosts. Rev. Fish. Biol. Fisheries, 6: 287-318.

WALLACE, R., and K. SELMAN. 1981. Cellular and dynamic aspects of oocyte growth in teleosts. Am. Zool., 21: $325-343$.

WARE, D. M. 1984. Fitness of different reproductive strategies in teleost fishes. In: Fish reproduction: strategies and tactics. G. W. Potts and R. J. Wootton (eds.). Academic Press, New York, p. 349-366.

WEST, G. 1990. Methods of assessing ovarian development in fishes: a review. Aust. J. Mar. Freshw. Res., 41: 199-222.

WOOTTON, R. J. 1984. Introduction: tactics and strategies in fish reproduction. In: Fish reproduction: strategies and tactics. G. W. Potts and R. J. Wootton (eds.). Academic Press, New York, p. 1-12.

1990. Ecology of teleost fishes. Chapman and Hall, London, 386 p. 
